\title{
Effects of feed fat on the composition and technological properties of milk and milk fat
}

\author{
VeikKo Kankare, Veujo Antila, Harri Miettinen and Jouko Setälä \\ Kankare, V., Antila, V., Miettinen, H. \& Setälä, J. 1992. Effects of feed fat on the \\ composition and technological properties of milk and milk fat. Agric. Sci. Fin. 1: \\ 239-246. (Agric. Res. Centre of Finland, Food Res. Inst., SF-31600 Jokioinen, Finland \\ and Valio, Research and Development Centre, Box 176, SF-00181 Helsinki, Finland.)
}

The aim of the study was to establish how the addition of rapeseed oil to a processed feed mixture affects the milk produced on commercial dairy farms as well as the composition and quality of the products made from that milk. In this study, replacing grain with processed feed mixture to which 2 or $4 \%$ rapeseed oil had been added was not found to affect milk yield or composition to any considerable extent.

As a result of the test feedings, the amounts of myristic and palmitic acid in the milk fat decreased and those of stearic and unsaturated fatty acids increased. This change in fatty acid composition can be viewed as nutritionally desirable, and it also had a good effect on the consistency of butter. During the second test period (4\% rapeseed oil) the cutting firmness figures of the butter were lowest, and in sensory evaluations the butter was also found to have the best consistency.

The test feeding had a slight beneficial effect on the composition of milk protein. The amount of casein nitrogen grew and that of NPN fell. However, the test feeding was not found to affect the quality of the market milk, cream, cheese or milk powder.

Key words: dairy cow, fatty acid composition, milk yield, protein composition, quality of butter, quality of cheese, rapeseed oil

\section{Introduction}

Especially during the winter, milk fat produced in Finland is extremely saturated and hard. As a result, and because of the large amounts of myristic $\left(\mathrm{C}_{14}\right.$ saturated $)$ and palmitic acid $\left(\mathrm{C}_{16}\right.$ saturated $)$ it contains, milk fat is considered an atherogenic fat which fails to meet the technological demands of the processing industry. There is, therefore, a clear need to make Finnish milk fat less saturated. Earlier experience has shown that this can best be achieved through feeding.

\section{Observations about the effects of feed fat}

It has been known for a long time that the composition of milk fat can be radically altered using fat additives (ORTH et al. 1956). Research on such procedures, e.g. the addition of tall oil or its ethyl esters to the feed, was started in Finland already in the early 1960's (ANTILA, V. et al. 1963 and 1965). The effects of feed fat on milk production and on milk fat composition have since been studied widely (CHRISTIE 1980, STORRY 1980 and 1981, PALMQVIST 1984, SYRJÄLÄ-QVIST 1986). 
Adding fat to feeds has generally been found to improve milk yield, especially when there is little natural fat in the basic feed. Small additions of fat increase the fat content, whereas large additions reduce it. When the feed fat content is raised above $6-7 \%$, the fermentation process in the rumen becomes disturbed, resulting in a drop both in yield and in fat content. Added fats have most frequently been found to reduce the protein content of milk (HuHTANEN 1989).

The fat content of milk can be raised and the composition of the fat changed by feeding the fat to the animal in a protected form, e.g. in capsules treated with formaldehyde. The linoleic acid content of milk fat can, for instance, be boosted to $35 \%$ in this way (FOGERTY and JOHNSON 1980). Such fat modification has not been applied to milk production in practice, however.

\section{Earlier tests by the Food Research Institute}

Researchers at the Food Research Institute - formerly the State Institute for Dairy Research - have studied the effects of various feeding factors on milk properties, especially on the composition of milk fat and the processing properties of milk. In a feed grain test, the amount of unsaturated fatty acids in the milk fats from cows fed oats was 28.7 $\%$ by weight and the iodine number around 32 ; when feeding barley the corresponding figures were 21.9 and 27 (KANKARE and ANTILA 1983 and 1984). Silage was found to soften the milk fat much more than a dry hay feed. The percentages of unsaturated fatty acids in the various groups were: silage groups $28.8 \%$ and dry hay groups $24.7 \%$ (KANKARE and ANTILA 1986).

Several series of tests were also carried out in the Agricultural Research Centre barn. The entire herd of 90-110 dairy cows was involved in the test in which the fat content of processed feed mixture was raised, mainly by adding rapeseed oil. When the fat content of the processed feed mixture was increased from 3.0 to $7.6 \%$, the total amount of unsaturated fatty acids rose from 25.7 to $41.8 \%$ and the iodine number from 29.2 to 41.4 . Even the largest addition of fat did not detract from milk yields, composition or taste. On the other hand, adding fat had a positive effect on processing properties, especially on the quality of the butter. Cutting firmness, fell from 164 to 74 , the latter corresponding to a relatively soft butter. Similar results were obtained in other feeding tests carried out by the Food Research Institute (KANKARE and ANTILA 1985 a, 1985 b, 1986).

Practical feeding tests on commercial farms were considered necessary to obtain further data.

\section{Material and methods}

\section{Purpose of the research}

The aim of the research was to establish how the addition of rapeseed oil to a processed feed mixture affects the milk produced on commercial farms, and the composition and quality of products made from that milk.

\section{Participants in the joint study}

The bodies involved in the study were: the Agricultural Research Centre Food Research Institute, the Research and Development Centre of Valio, the Hankkija Feed Industry and the Tuottajain Maito Dairy Co-operative.

\section{Feeds and feeding}

Fourteen farms along two milk collection routes covered by the Tuottajain Maito Co-operative were included in the study. The total number of dairy cows in the tests was 231 on average. The herds of the individual farms had between 8 and 28 milch cows.

The roughages used were silage and hay. Concentrates were fed according to requirements (SALO et al. 1982). The concentrates used were based mainly on grain and protein supplement. On average, $76 \%$ of the grain was oats and $24 \%$ barley. The average amount of protein supplement was 1 $\mathrm{kg}$ per day per cow. Minerals were fed according to 
requirements. In addition, whey powder and molassed sugar beet pulp were used on some of the farms.

The experiment was begun on January 30, 1989, and ended on April 16, 1989. The experiment was divided into four periods. During the pre-test period (two weeks) and the post-test period (three weeks), the farm fed the cows according to the normal schedule. During test periods 1 and 2 of three weeks each, the grain normally used for feeding was replaced by the test feed, to which either 2 or 4 $\%$ rapeseed oil had been added. The change-over was made gradually during the first week of each test period. The farms' feeding plans were adjusted according to the results of the feed analysis and milk urea content determination, obtained before the tests started. Apart from the grain and test feeds, every effort was made to keep the feeding pattern unchanged. Milk samples for testing were collected once a week.

\section{Sampling and analysis}

\section{Feeds}

Samples of the feeds normally used on the farms were taken before the experiment began. The feed composition has analysed by the NIR-method (HELLEMÄKI and MoIsIO 1983), and silage quality was determined using the titration method (MoIsIO and Heikonen 1989). The grain and hay samples were analysed by the Tuottajain Maito dairy and the silage by Valio's regional laboratory for southern Finland. Compositional analyses of the test feeds were made at the Valio Research and Development Centre. The crude fat determinations were carried out by Soil Analysis Service Ltd.

\section{Milk}

The composition, quality and urea content of milk samples was determined every week in the Valio's regional laboratory for southern Finland. The milk composition was determined using a standard IRmethod and the milk urea content with the method described by RAJAMÄKI and RAURAMAA (1984). Milk yield data averages were calculated each week from the Tuottajain Maito dairy's milk accounting figures, on the quantities collected. The Food Research Institute laboratory determined the milk composition, renneting properties (TERVALA et al. 1983), fatty acid content (ANTILA and KANKARE 1983) and nitrogen fractions, i.e. total nitrogen, casein and whey protein nitrogen and non-protein nitrogen (NPN)(Mc KENZIE 1970).

\section{Manufactured products}

Organoleptic characteristics were determined for the HTST pasteurized milks and creams and, in the case of creams, also their whipping properties. A sensory evaluation of the butter and cheese was made by both the Food Research Institute and the State Control Office for Dairy Products. Butter firmness was determined by a cutting firmness test (Peltola and HuUmonen 1957).

\section{Results}

\section{Composition and intake of feeds}

The average composition and intake of silage and hay are presented in Table 1. (The intake values are based on the information given by the farmers.)

Table 1. Average intake and composition of silage and hay.

\begin{tabular}{lcccc}
\hline & $\begin{array}{l}\text { Intake } \\
\mathrm{kg} / \text { day/ } / \\
\end{array}$ & $\begin{array}{c}\text { Cow matter } \\
\text { cow }\end{array}$ & $\begin{array}{c}\text { crude protein } \\
\% \text { DM }\end{array}$ & $\begin{array}{c}\text { crude fibre } \\
\% \text { DM }\end{array}$ \\
\hline SILAGE & & & & \\
X & 24 & 21.8 & 17.5 & 26.9 \\
SD & 6.1 & 2.6 & 2.5 & 1.8 \\
Min & 15 & 17.8 & 13.4 & 24.4 \\
Max & 35 & 27.9 & 25.4 & 30.0 \\
HAY & & & & \\
X & 5.1 & & 10.7 & 32.1 \\
SD & 1.9 & & 2.7 & 1.5 \\
Min & 1 & & 7.3 & 29.6 \\
Max & 9.5 & & 15.2 & 35.8 \\
\hline
\end{tabular}


With few exceptions, the quality of silages was within the acceptable range (MOISIO and HEIKONEN 1989).

The average intake and composition of the grain is shown in Table 2. Calculated as dry matter, grain accounted for about one third of the ration (approx. $5 \mathrm{~kg} /$ day/cow). Because of the large proportion of oats, the estimated crude fat content of the grain was quite high $(4.9 \%)$.

Table 2. Average intake and composition of grain and test feeds.

\begin{tabular}{|c|c|c|c|c|}
\hline & \multirow{2}{*}{$\begin{array}{l}\text { Intake } \\
\mathrm{kg} / \text { day/ } \\
\text { cow }\end{array}$} & \multicolumn{3}{|c|}{ Composition ( $\%$ dry matter) } \\
\hline & & $\begin{array}{l}\text { crude } \\
\text { protein }\end{array}$ & $\begin{array}{l}\text { crude } \\
\text { fibre }^{1)}\end{array}$ & $\begin{array}{l}\text { crude } \\
\text { fat }{ }^{1)}\end{array}$ \\
\hline \multicolumn{5}{|l|}{ GRAIN } \\
\hline $\mathrm{X}$ & 5.4 & 13.9 & 9.9 & 4.9 \\
\hline SD & 1.0 & 0.9 & 1.9 & 0.7 \\
\hline Min & 3.1 & 12.2 & 8.25 & 4.1 \\
\hline $\operatorname{Max}$ & 6.5 & 15.3 & 13.0 & 6.0 \\
\hline TEST FEED 1 & 11.1 & 6.6 & 3.2 & \\
\hline TEST FEED 2 & 11.8 & 6.8 & 5.5 & \\
\hline
\end{tabular}

${ }^{1)}$ For grain, estimated from feed tables (SALO et al. 1982)

Table 2 also shows the composition of the test feeds. The compounds used had a lower crude protein and crude fibre content than grain. The crude fat content of test feed 1 was below the figure estimated for grain. The raw materials of the test feeds are given in Table 3 .

Table 3. Raw materials of the test feeds (\%).

\begin{tabular}{lrr}
\hline & 1 & 2 \\
Barley & 57 & 55 \\
Oats & 20 & 20 \\
Molassed sugar beet pulp & 10 & 10 \\
Molasses & 3 & 3 \\
Rapeseed oil & 2 & 4 \\
Minerals & 5 & 5 \\
\hline
\end{tabular}

\section{Milk yield and composition}

Table 4 gives the average milk yield and composition for the various test periods. The effect of the added rapeseed oil was not found to be statistically significant in relation to any of the measured variables.
Table 4. Rapeseed oil added to concentrate and its effect on milk yield and composition on dairy farms $(n=14)$.

Pre-test Period 1 Period 2 Post-test

\begin{tabular}{|c|c|c|c|c|}
\hline $\begin{array}{l}\text { Rapeseed oil, } \\
\% \text { added }\end{array}$ & 0 & 2 & 4 & 0 \\
\hline Cows in milk, no. & 228 & 232 & 231 & 230 \\
\hline Milk, kg/day/farm & 295 & 298 & 310 & 307 \\
\hline Milk, $\mathrm{kg} /$ day/cow & 18.0 & 18.0 & 18.9 & 18.7 \\
\hline Protein, \% & 3.11 & 3.15 & 3.17 & 3.15 \\
\hline Fat, $\%$ & 4.27 & 4.27 & 4.28 & 4.26 \\
\hline Protein/Fat & 0.728 & 0.738 & 0.742 & 0.739 \\
\hline Lactose, $\%$ & 4.69 & 4.77 & 4.80 & 4.74 \\
\hline $\begin{array}{l}\text { Urea, mg/100 ml } \\
\text { Somatic cell }\end{array}$ & 22 & 22 & 24 & 25 \\
\hline counts, $x 1000 \mathrm{ml}^{-1}$ & 196 & 211 & 174 & 174 \\
\hline
\end{tabular}

The average milk yield $(\mathrm{kg} /$ day/farm or $\mathrm{kg} /$ day/cow) rose slightly during the experiment. The highest yield was achieved in period 2, (4\% rapeseed oil).

There were no appreciable changes in milk composition during the experiment. Protein content was slightly below the national average when the tests started $(3.11 \%$ vs. $3.16 \%)$. As the tests went on, however, the figure rose to the average. Throughout the test period milk fat content was close to the national average $(4.28 \%)$. Calculated for the entire test material, the correlation between protein content and fat content was significantly positive $(r=$ $0.65)$. The protein/fat ratio rose somewhat during the experiment, reaching its peak during period 2 .

The milk urea content increased somewhat during the experiment. There was a minor negative correlation between urea content and protein or fat content $(r=-0.24, r=-0.33)$.

\section{Effects on milk fat composition}

Figure 1 shows the milk fat iodine numbers and total quantities of unsaturated fatty acids at various stages of the tests. The softening of the fat is rather well illustrated by these figures.

The iodine values for the pooled milk samples rose from a starting level of 31.2 to 33.1 during the first test period and to 34.6 during the second. The difference between the starting level and period 2 


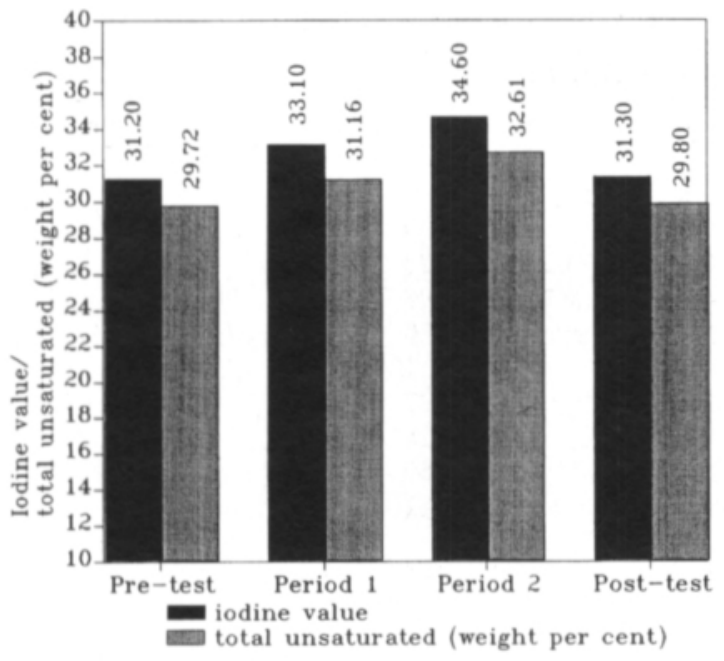

Fig. 1. Milk fat iodine numbers and total quantities of unsaturated fatty acids.

was found to be highly significant $(\mathrm{P}>0.001)$ when the iodine numbers of the farm milk were examined statistically. A similar rise was noted in the quantities of unsaturated fatty acids: pre-test $29.7 \%$, period $131.2 \%$ and period $232.6 \%$.

Figure 2 shows the amounts of certain key fatty acids at the various test periods. The amount of fatty acid $\mathrm{C}_{14}$, myristic acid, decreased only slightly, but the reduction in $\mathrm{C}_{16}$, palmitic acid, was highly significant statistically: pre-test $29.15 \%$, period $128.96 \%$ and period $226.79 \%$. The amount of $\mathrm{C}_{18}$, stearic acid, showed a small but distinct rise. The amount of $\mathrm{C}_{18: 1}$, oleic acid, grew faster than that of stearic acid (pre-test $21.7 \%$, period $122.4 \%$ and period $223.1 \%$ ). This was a statistically significant increase. The amount of $\mathrm{C}_{18: 2}$, linoleic acid, also showed an increase (pretest $1.19 \%$, period $11.40 \%$ and period $21.45 \%$ ).

\section{Effects on protein composition}

The total nitrogen content of the milk was analysed by test period and its breakdown into the various main fractions was established as shown in Table 5.

The amounts of non-protein nitrogen (NPN) during periods 1 and 2 were lower than during the re-

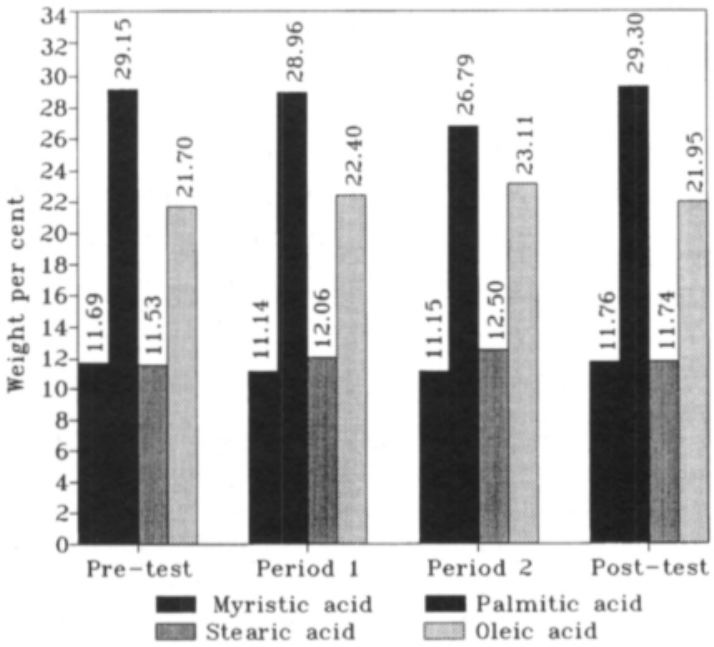

Fig. 2. Amounts of myristic, palmitic, stearic and oleic acids $(\%)$ in milk fats.

Table 5. Milk protein fractions, per cent of total nitrogen.

\begin{tabular}{lrrrr}
\hline & Pre-test & Period 1 & Period 2 & Post-test \\
\hline Casein, \% & 72.53 & 73.91 & 74.40 & 73.82 \\
Whey protein & 22.02 & 21.12 & 20.56 & 20.86 \\
NPN & 5.45 & 4.97 & 5.04 & 5.32 \\
\hline
\end{tabular}

ference periods, whereas the amounts of casein nitrogen were slightly higher. Whey protein content did not seem to vary systematically with the feeding. The highest value was found during the pre-test period and the lowest in period 2 .

\section{Milk products and their properties}

\section{Butter}

All the butter was made according to exactly the same manufacturing principles. The cutting firmness figures for spreading quality and firmness during the various test periods are given in figure 3 . The test feeding resulted in a distinct drop in cutting firmness figures.

During period 2, when the cutting firmness figures were at their lowest, the butter was also found 


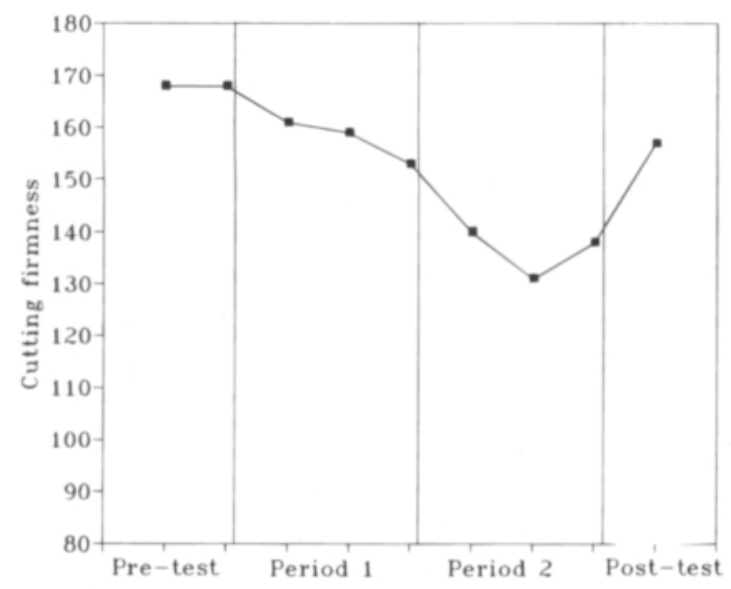

Fig. 3. Butter cutting firmness.

to have the best consistency on the basis of sensory evaluations.

The first evaluation of butter taste was carried out at the Food Research Institute after about two weeks' storage and at the State Control Office for Dairy Products after about three weeks. The results of both evaluations are given in figure 4. At the State Control Office for Dairy Products the highest marks were given to the butter produced during the test periods. The Food Research Institute evaluations found no distinct differences in butter taste between the various periods. The test feeding was

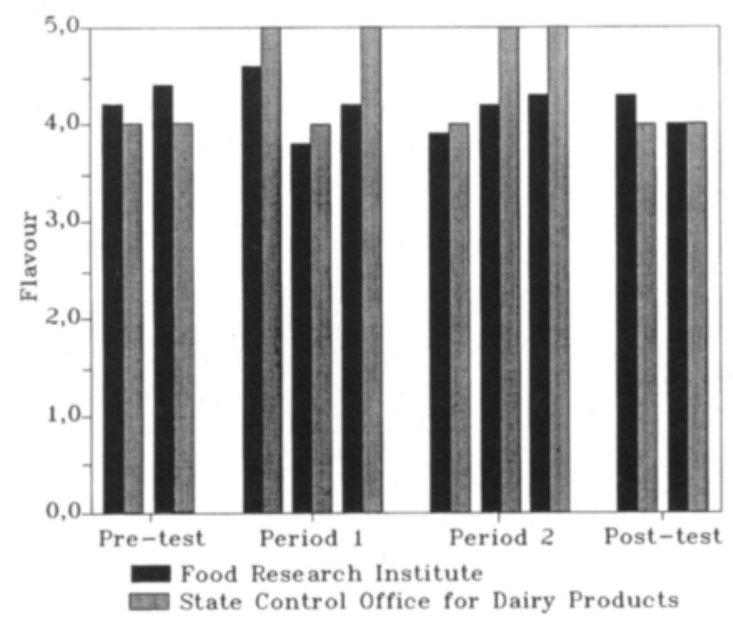

Fig. 4. Butter flavour, scale 0-5. thus found to have a very slight, but mainly positive, effect on butter taste. The keeping quality of all the butter produced was found to be good.

\section{Cheese}

To study the effects of the test feeding on cheese products, Edam cheese was manufactured from the test milk. All the test batches were made in the same way.

The figures illustrating milk renneting properties, renneting time and $\mathrm{A} 10$ value (= strength of coagulum), are given in figure 5. Coagulation time increased from $7 \mathrm{~min} 31$ seconds to $8 \mathrm{~min} 9 \mathrm{se}-$ conds between the pre-test period and period 2, while the A10 value fell from $28.7 \mathrm{~mm}$ to $26.3 \mathrm{~mm}$.

The slight deterioration in renneting properties

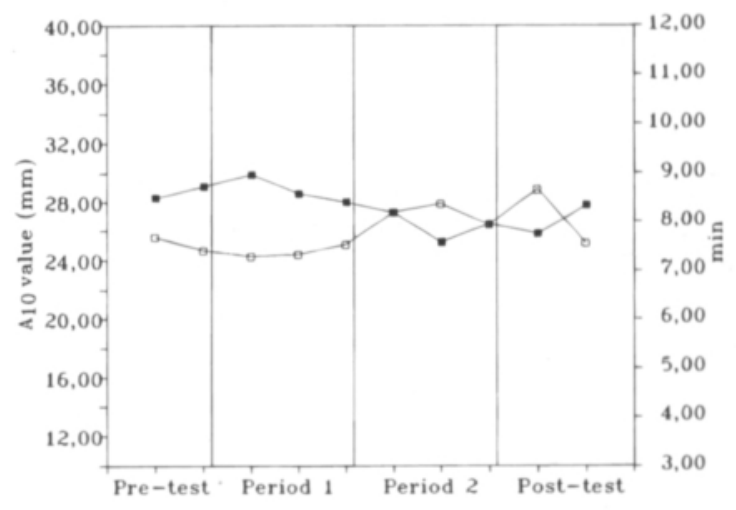

Fig. 5. Coagulum strength, $\mathrm{A}_{10}$ value (mm) ( $)$ and coagulation time $(\mathrm{min})(\square)$.

was due at least partly to a rise in milk pH.

The test cheeses were divided into classes $\mathrm{A}$ and B. No faults were found in the cheeses which could be attributed to the feeding method. The small deterioration in renneting properties can be counterbalanced in the manufacturing process.

\section{Market milk products}

The unhomogenized, unstandardized market milk and the $38 \%$ fat cream were judged faultless in both the Valio and Food Research Institute evaluations. 


\section{Milk powder}

One roughly $30 \mathrm{~kg}$ batch of full-fat ( $26 \%$ fat) spray-dried milk powder was made at each phase of the testing. No systematic differences were found between the batches.

\section{Discussion}

In this experiment, replacing grain with a processed feed mixture to which 2 or $4 \%$ rapeseed oil had been added did not affect milk yield or composition to any great extent.

The increase in yield during the test periods could well have been caused either by changes in the cows' lactation periods or by the test feeds. In some other experiments, the addition of fat to feed has been found to boost the milk yield of dairy cows (Hermansen 1989).

Adding fat to the feed has an effect both on milk protein and on fat content. The protein content usually drops as a result of the addition of fat and its quality also declines (CASPER and SCHINGOETHE 1989). In this experiment, however, there was no decrease in protein content; on the contrary, it increased slightly during the test periods. One reason for this may be the low protein content of the milk when the tests began, probably because of the predominance of oats in the diet. Replacing grain by the test feeds brought along an increase in the amount of barley in the processed feed mixture, and this may also have contributed to the increase in protein content. The changes in fat content were only minor, as were any changes in urea content.

The amounts of myristic and palmitic acid in the milk fat decreased and those of stearic and unsaturated fatty acids increased. This change in fatty acid composition can be viewed as nutritionally desirable, and it also had a good effect on the consistency of butter. The overall, conclusion to be drawn is that the desired kinds of changes in milk fat composition were achieved during the fat feeding tests, even though before the tests began the farms were applying a feed consisting predominantly of oats, which also tends to soften the milk fat.

The test feeding had a slight beneficial effect on the composition of the milk protein. The amount of casein nitrogen increased and that of NPN decreased. There were no systematic changes in the amount of whey protein. All in all, this limited analysis suggests that the test feeding had a good effect on the proportions of the various nitrogen fractions. Even so, renneting properties deteriorated somewhat. One reason for this was the slight rise in milk $\mathrm{pH}$ during the test period. Renneting properties can, however, be restored in the manufacturing process.

The test feeding was not found to affect the quality of market milk, cream or milk powder.

The study showed that changes in feeding on ordinary dairy farms achieve the same kind of results as those found in earlier tests with test groups or a complete test herd (KANKARE and ANTILA 1985 a, 1985 b, 1986). It may be expected that more and more milk producers will be interested in altering the composition of their milk to meet the demands of technology and nutrition more effectively.

\section{References}

AntIl.A, V. \& KanKare, V. 1983. The fatty acid composition of milk lipids. Milchwissenschaft 38: 478-481.

-, KÄrKKÄINEN, V.J., Ring, O. \& ANTILA, M. 1963. The fatty acids of tall oil and their ethyl and glyceryl esters as fodder ingredients. II The ethyl esters in the feeding of milk cows. Acta Agric. Scandinavica XIII: 2: 195-204.

-, MalkamÄKı, J., Ring, O., Uotila, M. \& AnTIla, M. 1965. Trials on the use of ethyl esters of tall oil fatty acids in dairy cattle feeding. Maatal. ja Koetoim. 19: 250-256.
CASPER, D.P. \& SChIngoethe, D.J. 1989. Model to describe and alleviate milk protein depression in early lactation dairy cows fed a high fat diet. J. Dairy Sci. 72: 3327 3335.

Christie, W. 1980. The effect of diet and other factors on the lipid composition of ruminant tissues and milk. Progress in Lipid Res. 17: 245-279.

FogERTY, A. \& JoHNSON, A. 1980. Influence of nutritional factors on the yield and content of milk fat: Protected polyunsaturated fat in the diet. Int. Dairy Fed. Bull. Doc. 
125: 96-104.

HellämÄKI, M. \& MoIsıo, T. 1983. Prediction of protein and fibre contents in silage by near infrared reflectance analysis. Milchwissenschaft 38: 14-15.

Hermansen, J.E. 1989. Effect of dietary fat in relation to milk yield and stage of lactation in dairy cows. Acta Agric. Scand. 39: 389-396.

HuHTANEN, P. 1989. Ruokinta ja maidon rasvapitoisuus. Maito ja Me 1, 1: 30-31.

KanKare, V. \& AnTILA, V. 1983. Kaura parantaa maitorasvan ominaisuuksia. Valt. Maitotal. Tutk.lait. Tied. Nro 182.

— \& ANTILA, V. 1984. The effect of feed grains of the fatty acid composition of milk fat. J. Agr. Sci Finl. 56: 33-38.

— \& AntILA, V. 1985 a. The effect of fat added to the feed on dairy cows on the composition milk fat. Meijeritiet. Aikak. XLIII, 1: 62-73.

— \& ANTILA, V. 1985 b. Väkirehun rasva parantaa maitorasvan ominaisuuksia. Valt. Maitotal. Tutk.lait. Tied. Nro 196.

— \& ANTILA, V. 1986. Öljyä sisältävä rypsirouhe ja -puriste lypsylehmien ruokinnassa. Valt. Maitotal. Tutk.lai. Tied. Nro 214.

— \& ANTILA, V. 1986. Heinä- ja säilörehuruokinnan vaikutukset maitorasvan koostumukseen. Valt. Maitotal. Tutk.lai. Tied. Nro 207.

Mc KenzIE, H.A. 1970. Milk Proteins Vol. I Academic Press, New York and London. p. 18-19.

Moisio, T. \& Heikonen, M. 1989. A titration method for silage assessment. Anim. Feed Sci. Technol. 22: 341-353.

PALMQVist, D. 1984. Use of fats in diets for lactating dairy cows. In: Fats in animal nutrition, Butterworths, London, p. 357-381.
Peltola, E. \& HuUmonen, O. 1957. Leikkauslujuus voin kiinteyden mittana. Karjantuote XL: 185-189 ja 225229.

RAJAMÄKI, S. \& RAURAMAA, A. 1984. The automated determination of urea in milk. Finnish Chemical Letters 2: 47 48.

SALO, M.-L., TUORI, M. \& KIISKINEN, T. 1982. Rehutaulukot ja ruokintanormit. Helsinki. 70 p.

STORRY, J. 1980. Influence of nutritional factors on the yield and content of milk fat: non-protected fat in the diet. Int. Dairy Fed. Bull. Doc. 125: 88-95.

- 1981. The effect of dietary fat on milk composition. In: Haresign, W. (ed.). Recent development in animal nutrition. Butterworths, London, p. 3-33.

SYRJÄLÄ-Qvist, L. 1986. Fat supplements in dairy cow feeding. Meijeritiet. Aikak. XLIV: 61-66.

Tervala, H.-L., Antila, V., Syvăjärvi, J. \& Lindström, U.B. 1983. Variations in the renneting properties of milk. Meijeritiet. Aikak. XLI, 2: 24-33.

Manuscript received December 1991

Veikko Kankare

Veijo Antila

Agricultural Research Centre of Finland

Food Research Institute

SF-31600 Jokioinen, Finland

Harri Miettinen

Jouko Setälä

Valio, Research and Development Department

Box 176

SF-00181 Helsinki, Finland

\title{
SELOSTUS \\ Rehun rasvan vaikutuksista maidon ja sen rasvan koostumukseen ja teknologisiin ominaisuuksiin
}

\author{
Veikko Kankare, Veijo Antila, Harri Miettinen ja Jouko Setälä \\ Maatalouden tutkimuskeskus ja Valion tutkimus- ja tuotekehityskeskus
}

Suomalainen maidon rasva on erityisesti talvikaudella varsin tyydyttynyttä. Sitä pidetään aterogeenisenä rasvana, joka ei teknologisilta ominaisuuksiltaankaan vastaa sille asetettuja vaatimuksia. Siksi on selvät tarpeet muuttaa maitorasvaa koostumukseltaan nykyistä tyydyttymättömämmäksi. Aikaisemmat kokeet ovat osoittaneet, että parhaiten tämä voidaan saavuttaa ruokinnallisin keinoin. Nyt tehdyn tutkimuksen tarkoituksena oli selvittää, mitä kaupalliseen väkirehuun tehty 2 ja $4 \%$ :n suuruiset rypsiöljylisäykset vaikuttavat maidon ominaisuuksiin. Koe suoritettiin käytännön kenttäkokeena lähiympäristön maidontuotantotiloilla.

Tehdyt rypsiöljylisäykset eivät vaikuttaneet maitotuotoksiin eikä maidon koostumukseen merkitsevästi. Koeruokin- nan tuloksena myristiini- ja palmitiinihappojen pitoisuudet pienenivät ja steariinihapon sekä tyydyttymättömien rasvahappojen osuus kasvoi. Tätä muutosta rasvahappokoostumuksessa voidaan pitää ravitsemuksellisesti edullisena. Toisen koejakson (4 \% rypsiöljyä) aikana voin leikkauslujuusarvot olivat pienimmät ja aistinvaraisissa arvosteluissa tämä voi todettiin parhaaksi kiinteydeltäăn.

Koeruokinnalla oli lievästi edullinen vaikutus maidon proteiinikoostumukseen. Kaseiinitypen osuus kasvoi ja eiproteiinitypen (NPN) osuus pieneni. Koeruokinnalla ei todettu olevan vaikutusta kulutusmaidon ja -kerman, juuston eikä maitojauheen laatuun. 